\title{
Islamic medical ethics in the 20th century
}

\author{
V Rispler-Chaim Department of Arabic, University of Haifa
}

\section{Author's abstract}

While the practice of Western medicine is known today to doctors of all ethnic and religious groups, its standards are subject to the availability of resources. The medical ethics guiding each doctor is influenced by his/her religious or cultural background or affiliation, and that is where diversity exists.

Much has been written about fewish and Christian medical ethics. Islamic medical ethics has never been discussed as an independent field of ethics, although several selected topics, especially those concerning sexuality, birth control and abortions, have been more discussed than others.

Islamic medical ethics in the 20th century will be characterised on the basis of Egyptian fatāwā (legal opinions) issued by famous Muslim scholars and several doctors. Some of the issues discussed by Islamic medical ethics are universal: abortions, organ transplants, artificial insemination, cosmetic surgery, doctor-patient relations, etc. Other issues are typically Islamic, such as impediments to fasting in Ramadan, diseases and physical conditions that cause infringement of the state of purity, medicines containing alcohol, etc.

Muslims' attitudes to both types of ethical issues often prove that pragmatism prevails and the aim is to seek a compromise between Islamic heritage and the achievements of modern medicine, as long as basic Islamic dogma is not violated.

\section{Key index terms}

Shari'a: Islamic law based on the Qur'ān and Hadith (Oral Tradition).

fatwā: a legal opinion often expressed in a question/ answer format.

mufti: a religious scholar who issues legal opinions. mașlaha: the principle of public benefit, which can sometimes be used to promote new legal ideas for which the Shari'a holds no reference.

The modern person rarely thinks of medicine as having

\section{Key words}

Islamic medical ethics; any religious or ethnic boundaries. The human body is usually perceived as a sophisticated and mysterious machine, whose life-span medicine is ever struggling to extend.

The newly found illnesses, their treatments and the medicines that have been developed in the leading scientific laboratories, are known all over the world. Muslim doctors like their non-Muslim colleagues have easy access to the latest medical advances via bulletins, the media, international conferences, etc.

While the question of uniformity of medicine in different places can be debated, the diversity of medical ethics systems is readily admitted. A glance through catalogues of medical libraries and catalogue of ethics reveals that there are Jewish medical ethics (1), Catholic medical ethics (2), etc.

In this paper I aim to show that there is also a body of Islamic medical ethics, which although almost overlooked as a distinct branch of medical ethics does exist and is even gaining in importance in the second half of the twentieth century. I say 'almost overlooked' because there are several books which do discuss certain aspects of Islamic medical ethics (3), but none of them refer to Islamic medical ethics as a field in its own right or as having practical relevance to contemporary Muslims.

It is in their ethical attitudes towards human life and the human body and the socio-religious norms associated with human life and the human body that societies differ. Thus, while the medicine practised by Muslims and for Muslims is generally the same medicine practised in the West today, the medical ethics is different. This means that the use or non-use of a renowned medical treatment by Muslim doctors will sometimes be guided more by ethics derived from Islamic law than by purely medical considerations.

According to one definition of 'ethics' it 'teaches us how to judge accurately the moral goodness or badness of any human action' (4). Therefore, ethics of all kinds mirror the most cherished ideas and principles of the society which adheres to them, medical ethics being no exception. Islamic ethics in general, are based on the foundations of Islam: The Qur'ān (the divine book which was revealed to Muhammad, the Messenger of God), the Hadith (the Oral Tradition as transmitted by Muhammad's Companions), and the Shari'a (Islamic 
law as developed by jurists based on the Qur'ān and the Hadith).

The literary genre in which ethics are often currently discussed is the $F a t \bar{a} w \bar{a}$ literature (legal responsa provided by certain religious scholars upon request from ordinary people or governmental authorities). This paper concentrates on twentieth century Egyptian fatāwā. Egypt is by no means a country governed on Islamic Shar'i principles, yet its daily newspapers, its periodicals and its media nowadays contain an increasing number of fatäwāa, a major portion of which deal with medical issues.

Muslims do not ask their religious scholars whether one form of treatment is medically more effective than another, or when to use a medication and for how long. Muslims usually wish to know the attitude of the Shari'a towards that treatment, and whether the intake of that particular medicine is permitted by Islamic law. Muslims need to be assured that modern medicine as offered to them is also acceptable by Shar'i Islamic norms.

The main characteristics of Islamic medical ethics, based on Egyptian fatāwā, are:

a) There is a constant attempt to base modern medical treatments in the classical sources of Islamic law.

b) The problems raised are pertinent predominantly to Muslims, or derive directly from the commandments and prohibitions of Islamic law.

c) When Islamic law and the state law on certain medical ethics are contradictory the fatwo $\bar{a}$ is issued to mediate.

d) Islamic medical ethics tend to be apologetic or to show the superiority of the Islamic way of life over that of other societies, especially in the West.

e) Islamic medical ethics are often inseparable from social and political issues.

These characteristics will be further illustrated in the following sections.

\section{[a]}

The best way to legitimise a modern medical treatment for Muslims is to prove that a similar practice appears already in the Qur'ān, can be associated with the Prophet Muhammad, or that it is somehow mentioned in the Islamic law books. The Islamic classical sources are consequently manipulated in order for at least an allusion to a modern medical innovation to be derived.

On the issue of the legitimacy of women's circumcision (khitān), for example, a subject not discussed in the Qur'ān but dealt with in the Oral Tradition of the Prophet, the mufti (the legalist who issues the fatāwā) quotes the opinions of the four schools of Islamic law (5). The mufti does not necessarily commit himself to any one school but merely surveys for the reader all existing possibilities.

On the subject of organ transplants one of the problems is whether an organ may be removed at all.
Here the Muslim scholars often refer to the Hanafi and Shāfi'i, schools of law, which allowed the belly of a dead person to be opened for the removal of a living fetus or a sum of money. The Māliki and Hanbali schools permitted only the removal of money (6). Organ transplantation is thus artificially connected to a different issue in Islamic law, so as to make analogy possible.

Another question with regard to organ transplantation is whether a body part from the dead defiles the body of the living. Again, the Hanafi school is quoted as determining 'not defiling' and the Mālikī as claiming that 'a human being, alive or dead, even if he is an unbeliever, is pure'. The Hanbali school asserted that 'a human being is pure when alive, he is defiled by death, and is purified again by the ablution after death' (6). On the basis of the legal sources, the mufti concluded that any organ removed from the dead body is pure.

The issue of transplants also requires the definition of the moment of death. The same mufti as above provides a definition taken, according to him, from Islamic law, but he does not mention the exact source. The definition says 'weakening of vision, limpness of the feet, bending of the nose, whitening of the temples and the stretching of the skin of the face and its losing the ability to wrinkle' are the signs of death.

If several patients are awaiting the same transplant, $\varnothing$ the mufti allows them to draw lots, just as the Prophet drew lots to choose the wife who would accompany himô on his journeys.

With regard to the question of the legitimacy of abortions, we again find a detailed survey of the various opinions of all schools of law, as well as the opinions of Shi'ites and Zyadīs (moderate Shi'ites), etc (7).

According to the Qur'ān and the Hadith, it is permitted to terminate a pregnancy if the mother is still breast-feeding. It is hence deduced that fertility in general can be temporarily limited (8).

All contraceptives are permitted to Muslims, in keeping with coitus interruptus, which had been practised already by the Prophet himself (9).

Artificial insemination is likened to the sexual approach to a woman in error (ie, not by her husband). This indicates that early Muslim jurists took into consideration the possibility of indirect impregnations. Deliberate insemination with the seed of a stranger is equated to adultery - a sin punishable by death according to Islamic law (10).

When an explicit reference to the classical sources of Islamic law cannot be found, modern Muslim scholars may resort to the element of 'public benefit' (maslaha). Thus, any positive procedure which does not contradict the general spirit of Islamic law and from which the public may benefit, is permissible even though the sources make no mention of it. The maslaha is one of the most useful tools of the Muslim jurist to fill legal lacunae.

Under the principle of maslaha, blood transfusions are also legitimate, despite the fact that the spilling out 
of blood is forbidden by Islamic law (11). It is acceptable to donate blood because this does not harm the donor, analogously to wet-nursing, which is allowed by Islamic law (12). It is even permitted to tranfuse the blood of a non-Muslim to a Muslim when the saving of life so requires (13). This is an obvious application of the principle of maslaha.

Even with regard to the recently discovered AIDS disease, we are provided with a quotation from chapter 7,33 of the Qur'ān: 'My Lord forbiddeth only indecencies, such of them as are apparent and such as are within' (14). The verse implies that those who follow the Qur'ān cannot possibly become afflicted (15).

Where there is no direct reference in the classical sources to the issue under discussion, we may sometimes find an extreme responsum, like the one that informs a woman for whom doctors recommended sterilisation because of the danger that her uterus might rupture following several caesarian sections, that sterilisation is forbidden because only God knows what is better (16).

This last example is an exception, in that it completely disregards the medical advice. It may be attributed to the character of the mufti or to the political climate in which he works. More common cases indicate great willingness on the part of the muftis to strive to ground modern medicine in classical Islamic sources. This can be done either on the basis of the theological approach that God knows all that ever happened and will happen, and that His knowledge is already included in His revealed text, or on the basis of the Qur'ān declaration, 'Allah desireth for you ease; he desireth not hardship for you' (17). Therefore, public need can often function as the justification for absorption of new ideas once the classical sources are exhausted.

\section{[b]}

Several problems that Islamic medical ethics must address relate to the commandments of Islam, and especially Ramadan. This is a daily fast, from before sunrise until after sunset, for an entire month.

It is hardly known in other religions. Difficult for healthy people, this duty is yet more critical for the sick, which is why so many fatāwa concern the month of Ramadan. Since fulfilment of this commandment assures great rewards in the Hereafter, even nonobservant Muslims insist on fasting.

In this regard, the muftis are often asked whether eye drops or nasal drops constitute breaking the fast. The usual answer is that eye drops do not, but nose drops, if absorbed via the nasal mucous membranes, do (18).

Another responsum states that according to the Hanafì and Shāfi'i $\bar{i}$ schools the use of drops and medicines is not considered eating, and therefore does not break the fast (19). Vitamins and glucose, if not taken through the mouth or the nose but injected, are not considered an infringement; an enema, however, is
(20).

The use of toothpaste may constitute a break of the fast if the toothpaste enters the oral cavity. Moreover, it is emphasised that the foul odour emanating from the mouth of a fasting Muslim during Ramadan is preferred by God to the smell of perfume (21).

Another question a Muslim doctor may have to face is if and when to persuade a Muslim patient to stop fasting for medical reasons. After all, the fast was decreed by God and any human being who interferes with the decree could be doomed as a sinner. The problem is serious and the answer is not clearcut. In one place it is stated that the patients themselves know best how far they can tolerate the fast: the decision should be left to them. On the other hand, the muft encourages the doctor to force the patient to stop fasting if his medical condition so requires (22). This last issue also touches upon doctor-patient relations, a topic that is discussed below.

Another phenomenon typical of Islamic law is the concern for bodily purity. Purification is required often - at least five times a day before prayers, during the days of Ramadan, and during the pilgrimage to Mecca, to mention only a few instances. Purification is usually performed with water, or with sand when water is scarce.

A woman inquiring about performing ablution while her leg is in a cast is recommended to wash with wate all parts of her body except the broken limb. This should be purified with sand (23). Other questions related to purity are whether female discharges constitute the end of the state of purity (24), and if a male who loses control of his bladder during prayer is considered impure.

Since drinking wine is forbidden by Islamic law, many questions arise about medicines that contain or are suspected of containing alcohol. At the beginning of the century, Rashīd Riḍā stated that medicines that utilise alcohol for disinfection are allowed and are not considered intoxicating (25). Chloroform is not considered intoxicating either, and therefore it is allowed in surgery (26). It is even permitted as a last resort to give wine to someone who is choking, if this is the nearest available liquid (27). Beer as a remedy for illness is completely banned, with the explanation that Muslim doctors can devise a better one (28).

Another issue for Islamic medical ethics is the treatment of a patient by a doctor of the opposite sex, especially the examination of women by male doctors This problem may have relevance for other religions where the segregation of females and males is recommended and where intermingling is permitted only among certain degrees of family relationships.

The solution is usually pragmatic, that is, women can be treated by male doctors for physical or psychiatric conditions when no woman doctor is available and when the case cannot be delayed. The only stipulation is, that the doctor be trustworthy as a devout Muslim (29). 


\section{[c]}

Female circumcision is nowadays forbidden by law in most Arab and Islamic countries. However, the custom is deeply rooted in upper Egypt, the Sudan and North Africa. The custom is founded in the Oral Tradition, and therefore religious scholars cannot overtly co-operate with a government in order to abolish it. We do hear from religious scholars that female circumcision is merely recommended in the Hadith. It is not mandatory (30). On the other hand, we hear that this type of circumcision is a good preventive measure against disease (31) or a means of decreasing female sexual desire and consequently of protecting the woman's and her husband's honour (32).

Sheikh Shaltūt, who accepts the preventive merits of female circumcision, admits it has no grounds in the sources. He warns, though, that the preventive merits are not a complete guarantee against immoral social behaviour. Only proper social education can ensure women's moral conduct, he concludes (33).

Sheikh Jād Al-Haqq agrees that female circumcision indeed restrains female sexual desire during puberty, and adds that this is very important in these times of densely populated neighbourhoods and the various sexual temptations that girls have to contend with (34).

Since female circumcision is mentioned in the Hadith, the muftis have never openly condemned it, a step that would serve the state law. Nor have the muftis ever encouraged khita $\bar{n}$. The result is that the custom is left to the individual believer's choice and thus neither the Shari'a nor the state law are violated by the muftis.

Another conflict of Shari'a law and state law was presented to Ridā in the beginning of the century: the government of what is now Yugoslavia introduced a law requiring post-mortem examination of every deceased person. This causes a postponement of the burial, which according to Islamic law must take place as soon after death as possible. Muslims in the country inquired whether as a result of this new decree they should emigrate to a country more favourable to Islamic law or remain, and abide by the law. In a courageous answer, Riḍā recommended staying and avoiding the ordeal of emigration. In this he in fact legitimised the priority of the state law over Shari'a law on the specific issue of post-mortem examinations (35).

Today too in modern states post-mortems are commonly performed for scientific or legal purposes. Many Muslims inquire of religious scholars if such examinations are acceptable to the Shari'a. The answer is usually that although the body of the deceased is violated by these examinations, the public benefits from the information obtained and that where homicide is suspected, justice can be done only when the cause of death is verified (36).

It is inevitable that Islamic law and modern state law sometimes contradict each other. From the examples presented above it appears that Islamic medical ethics are formulated more to effect a compromise between the two, than to antagonise either. [d]

Apologetics is a feature of Islamic medical ethics. This means that when subjects under discussion are also of serious consequences in the West, or when an idea arises from exposure to Western media, the muftis do not hesitate to attack Western values and morals and praise Islamic ones instead.

For example, the controversial matter of female circumcision came to public notice through the feminist movement in Arab countries as well as the tragic accidents that have befallen Muslim girls in Western countries as a result of operations performed in primitive conditions. In its defence, Jād Al-Haqq explains that female circumcision is even more necessary today because the temptations before girls are many, especially in Egypt's state of overpopulation (37).

In December 1985 female circumcision was again justified. Among the reasons given, one is told that khitän prevents the physical pleasure which one woman can draw from another, 'something which is common in countries where no female circumcision takes place' (33). Indirectly, the anonymous mufti claims that lesbian relationships result from lack of female circumcision and consequently he accuses governments that prohibit female circumcision of encouraging lesbianism.

Cosmetic surgery has become very popular and sophisticated in the West. However, when asked whether nose reconstruction is permitted by Islamicen law, Sheikh Sha'rāwì does not answer directly. He: develops a lengthy argument to prove that it is human beings who decide what the criteria of beauty are but they cannot produce even a statue according to these criteria. Beauty is a gift of God, he continues, which human beings cannot understand. Therefore, we are not allowed to measure beauty by human standards. Sha'rāwī evidently does not believe surgery of this kind can be supported by Islamic law (38).

The fear expressed by all muftis is that the development of plastic surgery may lead people to 'change the creation of God'. However, most muftīs, when they realise that the physical defect causes a person much suffering, do justify cosmetic procedures, but for psychological reasons (39). Further examples of Islamic apologetics are the following. Some diseases are reported to be directly transferred from pigs to people. Among them is: epidemic influenza. Many viral diseases are transferred by pigs to people; two of them are: Japanese encephalitis and foot and mouth disease (40). All these diseases are mentioned to show the wisdom of Islamic dietary laws, which prohibit the eating of pork.

The toothpick is proudly claimed to have been first used by the Prophet to clean the mouth of bacteria and to sweeten the breath; but the West only came to realise the importance of toothpicks for dental health in the twentieth century (41).

On the AIDS disease, Islamic medical ethics are the most apologetic. AIDS is said to result from sexual 
promiscuity in European and American societies. This disease attacks only those who practise abnormal sexual activities. It is God's punishment for sexual deviants. Islam, on the other hand, prohibits homosexuality, abnormal sex and adultery. 'Even Europeans and Americans realise today that AIDS is Heaven's curse' (42).

In the West, ethical discussions of AIDS consider the sick, where they should be treated and by whom, who should pay for their treatment and for how long, whether they can remain in their college, neighbourhood, workplace etc. Islamic medical ethics concentrates exclusively on the reasons for the disease and the lessons to be learnt from it; no opportunity is missed of boasting of Islam's moral superiority.

\section{[e]}

Islamic medical ethics are always somehow connected to contemporary social and political issues. Shaltūt, who was Sheikh Al-Azhar, the religious University of Cairo, in the 1950s and early 1960s, said with regard to abortions and family planning, that it was an absurdity to think of a state law which limits the number of children allowed per family (43). Shaltūt did not object to family planning for highly fertile women or women with genetic and mental diseases. He insisted that the planning treat each case individually. In the 1950s and 1960s the political establishment tried to solve Egypt's problem of over-population by adopting legislation to limit the number of children permitted per family. Shaltūt, using ethical grounds, rejects this political intervention. A similar response, also refuting such a state endeavour, was issued by Jād Al-Haqq (44). In June 1985 Sheikh Hasan Ma'mūn said (45) on the same issue that poverty and wealth were temporary conditions, so over-population and poverty were not sufficient reasons for restricting child-bearing. Besides, he added that such restrictions contradicted the principles of the Shari'a.

In the case of birth control, at least, the medical issue is used by religious scholars to harry the secular establishment with its demo-political goals. The subjects of post-mortem examinations, female circumcision, AIDS and others, which have been considered at some length above, also have sociopolitical significance and are therefore relevant in the context of this section too.

\section{[Summary]}

Although some issues that Islamic medical ethics deals with are typical for Islam and pertain primarily to Muslims, others are common to most religions. These include the legitimacy of abortions, organ transplants, artificial insemination, cosmetic surgery, doctorpatient relations, etc.

Islamic medical ethics displays a solid acquaintance with purely medical material, and they are up-to-date with regard to the most recent discoveries. Since medicine is constantly developing, we may expect Islamic medical ethics to follow its progress and provide Muslims with the legitimacy necessary for the adoption or rejection of each innovation.

Those responsible for the formulation of modern Islamic medical ethics are known religious figures and several Muslim doctors. The general trend of these ethics, as evinced in twentieth-century Egypt, is to keep in step with scientific progress as long as basic Islamic doctrine is not endangered and as long as the public benefits. Pragmatism seems to be the keynote. This does not mean that deviations from this general trend cannot occur. When they do it is the result of either the personal religious convictions of $\vec{a}$ predominant religious figures and trusted doctors or of the political regime of the time. All in all, medical ethics, like other ethics, should always be judged with reference to their place and period. Only basic ethics in a society or religion never change. Others change with time and location, and it is these which make the study of ethics worthwhile and dynamic.

\section{Acknowledgement}

I am grateful to the Dayan Center at Tel Aviv University for permission to use their archives and to Mrs Y Braunstein for her assistance in gathering the material.

\section{A short bibliography}

Albar M A. Human Development as revealed in the Hol Qur'ān and Hadith, Jeddah, Saudi Publishing ang Distributing House, 1986. Bouhdiba A. Sexuality in Islam, London: Routledge and Kegan Paul, 1982. Ghanem I. Islamic Medical furisprudence, London: Probsthain, 1982. Hathout H. Islamic Perspectives in Obstetrics and Gynaecology, Faculty of Medicine, University of Kuwait, 1986. Musallam B. Sex and Society in Islam: Birth Control before the Nineteenth Century, Cambridge: Cambridge University Press 1983.

DrVardit Rispler-Chaim is a graduate of the University of California at Berkeley, where she obtained a PhD degree in September 1985. Since then she has been employed as a Lecturer at the University of Haifa, Israel, in the Department of Arabic. Her specialty is Islamic Law with emphasis on its adjustment to changing circumstances. Her teaching and research include topics such as human rights in Islam, insurance practices in the past and the present, the prohibition of interest, medical ethics and social issues in Islam.

\section{References}

(1) Rosner F. Modern medicine and fewish law. New York: Yeshiva University, Dept of Special publications, 1972. Jakobovits I. Fewish medical ethics New York: Bloch 1959.

(2) Mc Fadden C J. Medical ethics. Philadelphia: F A Davis Co, 1967, especially the chapter entitled 'Ethical and $O$ religious directives for Catholic hospitals': 439-446. 
(3) For example the following: Musallam B. Sex and society in Islam: birth control before the nineteenth century. Cambridge: Cambridge University Press, 1983. Bouhdiba A. Sexuality in Islam. London: Routledge and Kegan Paul, 1985. Ghanem I. Islamic medical jurisprudence. London: Probsthain, 1982.

(4) See reference (2): chapter 1.

(5) Makhlūf Ḥ M. Fatāwā Shar iyya waBuhūth Islämiyya. Cairo: Dār Al-Kātib Al-'Arabi, 1952; 2:208-209. The four schools of law are the Hanafi, Shäfi Māliki and Hanbali. Their legal activity crystallised around the eighth and ninth centuries.

(6) Jād Al-Haqq J A. In: Al-Fatāwā Al-Islāmiyya Cairo: Dār Al-Iftā' Al-MiSriyya 10: 3702-3715 (first issued 1979 Dec 5).

(7) Jād Al-Ḥaqq J A. In: Al-Fatāwā Al-Islāmiyya 9: 30933109 (first issued $1980 \mathrm{Dec} 4$ ).

(8) Shaltūt M. Al-Fatāwā. Cairo: Dār Al-Qalam, 1966: 293-297.

(9) Jād Al-Haqq J A. In: Al-Fatāwā Al-Islämiyya 9: 3110 3115 (first issued $1980 \mathrm{Dec} 29$ ).

(10) Shaltūt M. Al-Fatāwāa, 325-329. Majallat Al-Azhar 1981 Nov: 314.

(11) Makhlūf Ḥ M. Fatāwā Shar'iyya waBuhūth Islāmiyya. Cairo: Matba'at Al-Madanī, 1971; 2:218.

(12) Al-Mushidd A. Al-Ahräm 1985 Jul 26:15.

(13) Al-Mushidd A. Al-Ahrām 1985 Jul 1:12.

(14) The translation is from Pickthall M M. The glorious Koran. USA: Mentor Books, 1976.

(15) 'Abd Allah W A. Majallat Al-Azhar. 1987 Jun: 13991402.

(16) Al-Sha'rāwī M. Al-Fatāwā. Cairo: Maktabat Al-Qur'ān n d 3:29.

(17) Qur'ān 2, 185.

(18) Hamza 'A. Al-Ahrām. 1984 Jun 24: 12.

(19) Al-Ahräm. 1982 Jul 1: 13.

(20) Hamza 'A. Al-Ahrām. 1984 Jun 12: 12.

(21) Hamza 'A. Al-Ahrām. 1984 Jun 11: 12.

(22) Lāshīn M S. Al-Fumhüriyya. 1983 Jun 19: 5.

(23) Abū Farhạ Al-H. Al-Ahrām. 1983 Aug 19: 13.
(24) Al-I'tiṣām. 1985 Nov-Dec: 18-21.

(25) Rị̣ā R. Fatāwāa . Beirut: Dār Al-Kitāb Al-Jadīd, 1970; 4:1603.

(26) Al-Umma Al-Islämiyya. 1985 Sept: 8.

(27) Makhlūf H M. In: Al-Fatāwā Al-Islämiyya 7: 1073 (first issued 1952 Nov 15); Al-Umma Al-Islämiyya 1985 May: 7.

(28) Al-Umma Al-Islämiyya 1985 Feb: 7.

(29) Șaqr 'A. Al-Ahrām 1985 Feb 15: 13, Al-Umma AlÍslämiyya 1985 Feb: 7, Al-Sha'rāwī M. 100 Su'āl wafawābfi Al-Fiqh Al-Islāmī. Cairo: Al-Turāth AlIslāmī n d; 2: 9-10.

(30) Majallat Al-Azhar 1981 Nov: 315.

(31) Ridā R. Fatāwā 1: 245-246; the fatāwā is dated 1964.

(32) Al-Umma Al-Islämiyya 1985 Dec: 9.

(33) Shaltūt M. Al-Fatāwā: 330-334.

(34) Jād Al-Haqq J A. In: Al-Fatāwāā Al-Islāmiyya 9: 3119_ 3125 (first issued 1981 Jan 29).

(35) Ridā R. Fatāwā 3: 851 .

(36) See reference (5) 2: 219-223. Majallat Al-Azhar 1982 Jan: 650. 'Abd Al-Fattāh A M. Al-Ahräm. 1983 Apr 15: 13.

(37) Jād Al-Haqq J A. In: Al-Fatāwā Al-Islämiyya 9: 3119_ 3125 (first issued 1981 Jan 21).

(38) 100 Su'āl wafawāb, 14-16.

(39) Al-Umma Al-Islämïya 1985 Nov: 7 (teeth straightening); Șaqr 'A. Māyū 1985 Dec 2:11 (removal of a sixth finger from a child's hand). A similar case can also be found in Al-Fatāwā Al-Islämiyya 7: 2569-2570 (first issued 1968 May 22).

(40) Al-I'tișām 1985 Nov-Dec: 18-19, Hitti Y K. Hitti's English-Arabic medical dictionary. Beirut, Lebanon: Librairie du Liban, 1982. Dorland's illustrated medical dictionary. Philadelphia: Saunders, 1981.

(41) Al-I'tișām 1985 Nov-Dec: 18-19.

(42) Al-I'tișām 1985 Nov-Dec: 18-21. Majallat Al-Azhar 1987 Jun: 1399-1402.

(43) Al-Fatãwā 293-297.

(44) Jād Al-Haqq J A. Al-Da'wa 1985 Apr: 47.

(45) Ma'mūn H. Al-Fatāwā Al-Islāmiyya 7: 2546-2547. 